\title{
Mutations in the exon 7 of Trp53 gene and the level of p53 protein in double transgenic mouse model of Alzheimer's disease
}

\author{
Jolanta Dorszewska ${ }^{1}$, Anna Oczkowska ${ }^{1}$, Monika Suwalska ${ }^{1}$, Agata Rozycka ${ }^{2}$, Jolanta Florczak-Wyspianska ${ }^{3}$, \\ Mateusz Dezor ${ }^{1}$, Margarita Lianeri ${ }^{2}$, Pawel P. Jagodzinski ${ }^{2}$, Michal J. Kowalczyk ${ }^{4}$, Michal Prendecki ${ }^{1}$, Wojciech Kozubski ${ }^{3}$ \\ ${ }^{1}$ Laboratory of Neurobiology, Department of Neurology, Poznan University of Medical Sciences, ${ }^{2}$ Department of Biochemistry and \\ Molecular Biology, Poznan University of Medical Sciences, ${ }^{3}$ Chair and Department of Neurology, Poznan University of Medical Sciences, \\ ${ }^{4}$ Department of Dermatology and Venereology, Poznan University of Medical Sciences, Poznan, Poland
}

\begin{abstract}
Alzheimer's disease (AD) leads to generation of $\beta$-amyloid $(A \beta)$ in the brain. Alzheimer's disease model PS/APP mice show a markedly accelerated accumulation of $A \beta$, which may lead to apoptosis induction e.g. in cells expressing wild-type p53. The TP53 gene is found to be the most frequently mutated gene in human tumour cells. There is accumulating evidence pointing out to the contribution of oxidative stress and chronic inflammation in both $A D$ and cancer. The purpose of this study was to analyze exon 7 mutations of the murine Trp53 gene and AB/A4 and p53 protein levels in PS/APP and control mice.

The studies were performed on female double transgenic PS/APP mice and young adults (8-12 weeks old) and agematched control mice. The Trp53 mutation analysis was carried out with the use of PCR and DNA sequencing. The $A \beta / A 4$ and $p 53$ levels were analyzed by Western blotting.

The frequency of mutations was almost quadrupled in PS/APP mice (44\%), compared to controls (14\%). PS/APP mice with the A929T and A857G mutations had a similar $p 53$ level. In cerebral gray matter of PS/APP mice the level of $p 53$ positive correlated with the level of $A \beta$ protein $\left(R_{S}=+0.700, p<0.05\right)$. In younger control animals, the T854G mutation was related to $p 53$ down-regulation, while in aging ones, G859A substitution was most likely associated with over-expression of $p 53$. In silico protein analysis revealed a possibly substantial impact of all four mutations on p53 activity. Three mutations were in close proximity to zinc-coordinating cysteine residues.

It seems that in PS/APP mice missense Trp53 exon 7 mutations may be associated with the degenerative process by changes of $p 53$ protein function.
\end{abstract}

Key words: Trp53 mutations, $p 53, A \beta / A 4$ proteins, PS/APP mice.

\section{Introduction}

Alzheimer's disease (AD) is characterized both clinically by the decline of cognitive functions, such as memory, and pathologically by the presence of numerous senile plaques (SPs) and neurofibrillary tangles (NFTs) [2,3,28,40,46,51]. Neurofibrillary tangles consist of hyperphosphorylated tau protein, whereas 
SPs are composed of amyloid $\beta$-protein (A $\beta$ ). Transgenic PS/APP mice carrying mutant amyloid precursor protein (APP) and presenilin-1 (PS1) show a markedly accelerated accumulation of the 42 amino acid long form of A $\beta$ (AB42) into visible deposits [26]. Transgenic PS/APP mice can therefore be used as experimental AD models. Ohyagi et al. [43] have shown that intracellular A 342 directly activates the TP53 promoter, resulting in p53-dependent apoptosis. Accumulation of both $A \beta 42$ and $p 53$ was found in degenerating neurons in transgenic simulated $A D$ mice and in humans with $A D[32,43]$. Aging subjects and $A D$ patients show an increased level of a mutant-like conformation state of the p53 protein in peripheral blood cells [33]. Lanni et al. [33] have shown that a conformation change of p53 may lead to a partial loss of its activity and dysfunction of cell cycle proteins. Moreover, tumour suppressive p53 is critical in preventing cancer due to its ability to trigger proliferation arrest and cell death upon the occurrence of a variety of stressful conditions [15].

Human p53 contains 393 amino acids, encoded within the TP53 gene, located at the 17p13.1 locus [7]. The TP53 gene is found to be the most frequently mutated in human cancers with the occurrence level of about $50 \%$. Deletions, rearrangements, and retroviral insertional inactivations of the $\operatorname{Tr} 553$ analogue gene have been found in mice. Furthermore, $p 53^{+/-}$and $p 53^{-/-}$mice have been found to develop a broad spectrum of tumours, including lymphomas, osteosarcomas, fibrosarcomas, and medulloblastomas [22,29].

There is accumulating evidence pointing out to the contribution of oxidative stress and chronic inflammation in both $A D$ and cancer [19]. Lanni et al. [34] suggested that p53 protein may play a significant role in the degenerative process and cancerogenesis. The study by Serrano et al. [50] has shown an elevated expression of a mutant p53 in elderly AD mice. Fiorini et al. [18] have shown that p53 defects may alter the expression of mitochondrial proteins in murine brain. On the other hand, transgenic mice with truncated p53 exhibit enhanced resistance to spontaneous tumours, but show reduced longevity [54].

The presence of mutations in exons 4 to 8 of the TP53 gene has been found in a variety of neoplasms, including chronic lymphocytic leukaemia (17.3\%) [10], colorectal cancer (42.3\%) [57], lung cancer (39.4\%) [9], bladder cancer (36.2\%) [24], and head and neck carcinoma (22\%) [38]. Furthermore, mutations in the
TP53 gene have been found more often in higher malignancy grade scores (5.9\% in grade I compared to $53.9 \%$ in grade III) in bladder tumours, while the mutation rate was sex and age independent [24].

The purpose of the study was to analyze mutations in exon 7 of the murine Trp53 gene and estimate the levels of $A \beta / A 4$ and $p 53$ proteins in about 7-month-old PS/APP mice. The results were compared to control mice of similar age and to a group of younger mice (8-12 weeks old).

\section{Material and methods}

\section{Animals}

The study involved nine about 7-month-old double transgenic PS/APP female mice (B6.Cg-Tg(APP695) 3DBo $\operatorname{Tg}($ PSEN1dE9)S9DBo/J strain, Jackson Laboratory, USA). PS/APP mice deposit neurotoxic $A \beta$ at 6-8 months of age. The control group consisted of fourteen females (C57BL/6) strain, Jackson Laboratory, USA), including six young adults (8-12 weeks old) and eight moderately old mice (7 months old).

Murine brains were isolated and divided into cerebral grey matter (GM), subcortical white matter (WM) and cerebellum (C).

This study was approved by local research ethics committees and the Polish Ministry of Environment.

\section{DNA analysis}

DNA for genotyping and racial purity checks was isolated from murine blood by standard methods. Racial purity was confirmed by PCR. Doubled 20 ng genomic DNA (gDNA) samples were amplified with the use of primers targeting exon 7 (NM_011640.3, 5'-GTGAGGTAGGGAGCGACTT-3'; 5'-CCTACCACGCGCGCCTTCCT-3'), yielding a 175 bp product. The PCR was carried out in $25 \mu$ l of the mixture containing: $13.7 \mu$ l of Mili-Q water, $2.5 \mu \mathrm{l}$ of Laemmli Sample Buffer (Bio-Rad, USA), $2 \mu \mathrm{l}$ of primers solution, $2 \mu \mathrm{l}$ of dNTPs (Novazym, Poland), $0.8 \mu \mathrm{l}$ of Allegro Taq polymerase (Novazym, Poland), and $2 \mu \mathrm{l}$ of tested DNA. The annealing temperature has been optimized to $62^{\circ} \mathrm{C}$, the PCR was carried out for 30 cycles. The quality of the product was estimated by standard gel electrophoresis.

Polymerase chain reaction (PCR) product was purified and sequenced according to the standard protocol in the external unit: the Laboratory of Molecular Biology Techniques at the Faculty of Biology, Adam Mickiewicz University, Poznan, Poland. The samples 
were analyzed with sequencer 3130xl Genetic Analyzer (Applied Biosystems HITACHI, USA). All samples showing the presence of mutations were re-analyzed to confirm the presence of specific changes. The sequencing results were analyzed using the BioEdit software based on a reference sequence.

\section{Western blotting}

Dissected brain tissues were lysed and homogenized with the use of a radioimmunoprotein assay (RIPA) buffer (50 mM Tris- $\mathrm{HCl}, \mathrm{pH}$ 7.2; $150 \mathrm{mM} \mathrm{NaCl}$; 1\% IGEPAL CA-630; 0.05\% sodium dodecyl sulfate; $1 \%$ sodium deoxycholate), supplemented with a protease inhibitor cocktail for mammalian cell extracts (Sigma, USA) [16:1] and phenylmethylsulfonyl fluoride (Sigma, USA) in isopropanol $(10 \mathrm{mg} / 100 \mu \mathrm{l})$. The samples were then centrifuged and the pellet was discarded [42].

Protein aliquots (40 $\mu \mathrm{g} /$ lane) were electrophoresed in $7.5 \%$ polyacrylamide gels and transferred onto nitrocellulose filters. The filters were exposed to anti-p53 goat polyclonal antibodies (Ab) (C-19, IgG, $200 \mu \mathrm{g} / \mathrm{ml}$, Santa Cruz, USA) or to anti-A $\beta /$ A4 murine monoclonal $\mathrm{Ab}\left(\mathrm{B}-4, \operatorname{lgG}_{2 a}, 200 \mu \mathrm{g} / \mathrm{ml}\right.$, Santa Cruz, USA), at dilutions of $1: 500$.

Subsequently, the filters were incubated with secondary Abs, either murine anti-goat IgG-HRP (400 $\mu \mathrm{g} / \mathrm{ml}$, Santa Cruz, USA) or goat anti-mouse IgG-HRP (400 $\mu \mathrm{g} / \mathrm{ml}$, Santa Cruz, USA) respectively, at dilutions of 1 : 2000. Peroxidase Boehringer Mannheim blocking reagent (BMB) was added (BM Blue POD Substrate, Roche-Applied Science, Germany) to stain the immunoreactive bands. The $A \beta / A 4$ and $\mathrm{p}-53$ protein levels were analyzed on separate nitrocellulose filters. The band area was registered using a Quantity One densitometer (GC-710, BioRad, USA). The quantification was performed by measuring the area of registered immunoreactive bands.
Subsequently, the stripping of $A \beta / A 4$ and $p-53$ filters was performed with the stripping solution (62.5 mM TRIS/HCl with 2\% SDS and 0.7\% 2-merkaptoethanol in Mili-Q water) to remove the primary and the secondary Abs. Then, the filters were incubated with the anti- $\beta$-actin murine monoclonal $A b$ (C-4, IgG, $200 \mu \mathrm{g} / \mathrm{ml}$, Santa Cruz, USA), at dilution of 1 : 500. Subsequently, the processes of incubation with secondary $\mathrm{Ab}$ and staining were performed. The uniform $\beta$-actin bands confirmed the validity of the method.

\section{Statistical and in silico analysis}

Differences in protein levels were assessed with the use of the nonparametric Kruskal-Wallis test for unlinked variables. Spearman's ranked correlation test was used for correlation analysis.

BioEdit, CLC Sequence Viewer, Protein Workshop [39], and IARC TP53 R15 Database [31,45] were used for in silico analysis.

\section{Results}

Trp53 exon 7 sequencing showed the presence of 4 different missense mutations in blood of the mice. One mutation was found in a 7-month-old control mouse, another in an 8-12-week-old one. Two mutations were found in PS/APP mice. Both were repeated twice, thus $44 \%$ of PS/APP mice were found to carry a missense mutation, compared to only $14 \%$ of the control mice (Table I, Figs. 1A-D).

The 8-12-week-old control mouse showed the presence of a T854G mutation, resulting in Tyr233Asp substitution (Fig. 1A). The 7-month-old control mouse showed a G859A mutation, causing Met234lle substitution (Fig. 1B). The 7-month-old PS/APP mice showed the presence of two other mutations: A929T, resulting in Ser258Cys substitution; and A857G, replacing Met to Val also at position 234 (Figs. 1C, D).

Table I. Identified Trp53 exon 7 mutation: a summary

\begin{tabular}{lcccc}
\hline Mice & DNA mutation & Amino acid substitution & \multicolumn{2}{c}{ Mutation frequency } \\
\cline { 3 - 4 } & & & $n / N$ & $n / N / \%$ \\
\hline Control 8-12 week old & T854G & Tyr233Asp & $1 / 6$ & $2 / 14 /$ \\
\hline Control about 7 month old & G859A & Met234lle & $1 / 8$ & $4 / 9 /$ \\
\hline PS/APP about 7 month old & A929T & Ser258Cys & $2 / 9$ & $44 \%$ \\
\cline { 2 - 4 } & A857G & Met234Val & $2 / 9$ & \\
\hline
\end{tabular}

$n$-number of animals with mutations, $N$ - total number of animals in the group, \% mice with mutations 
A
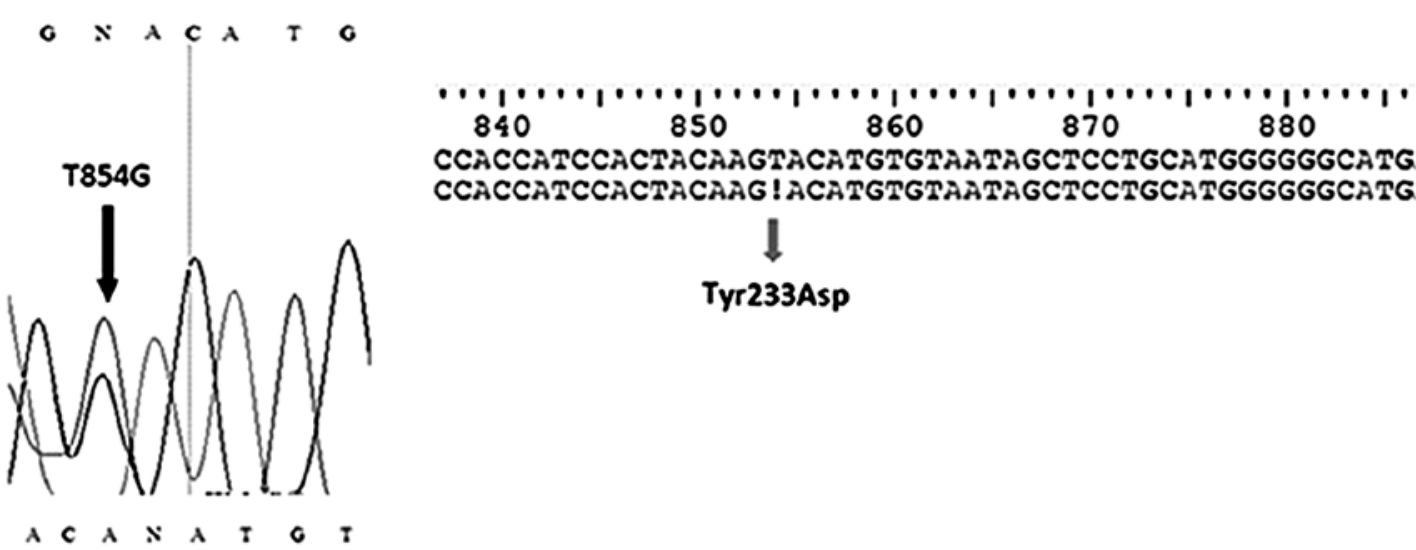

B

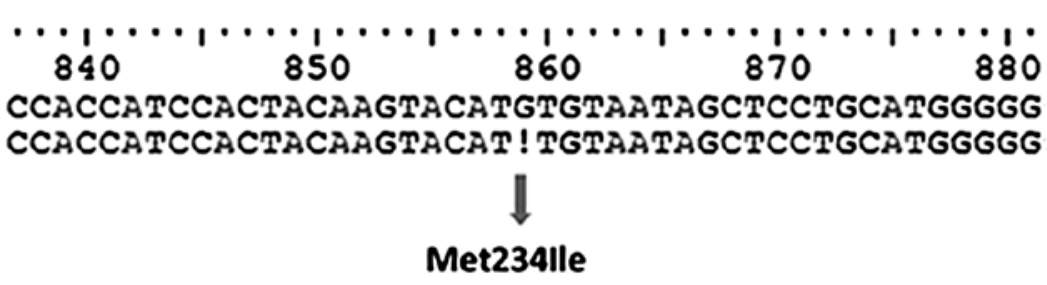

C

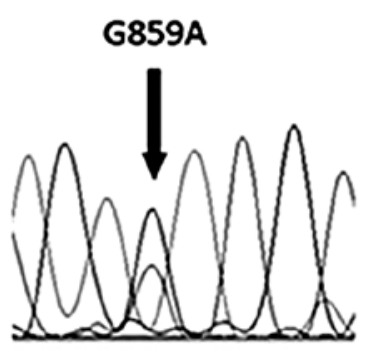

Met234lle
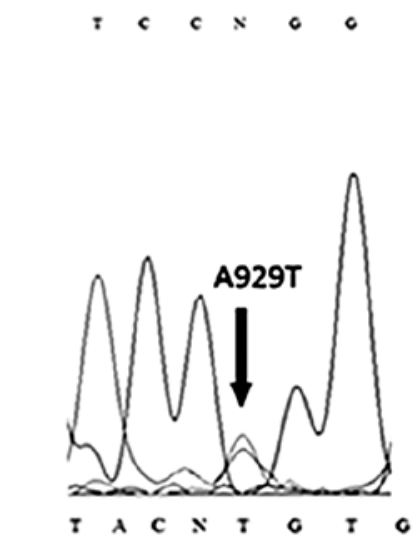

890

900

910

920

930

SAACCGCCGACCTATCCTRACCATCATCACACTGGAAGACTCCAGgTO GAACCGCCGaCCTATCCTTACCATCATCACACTGGAAGACTCC! GGTAG

Ser258Cys

D
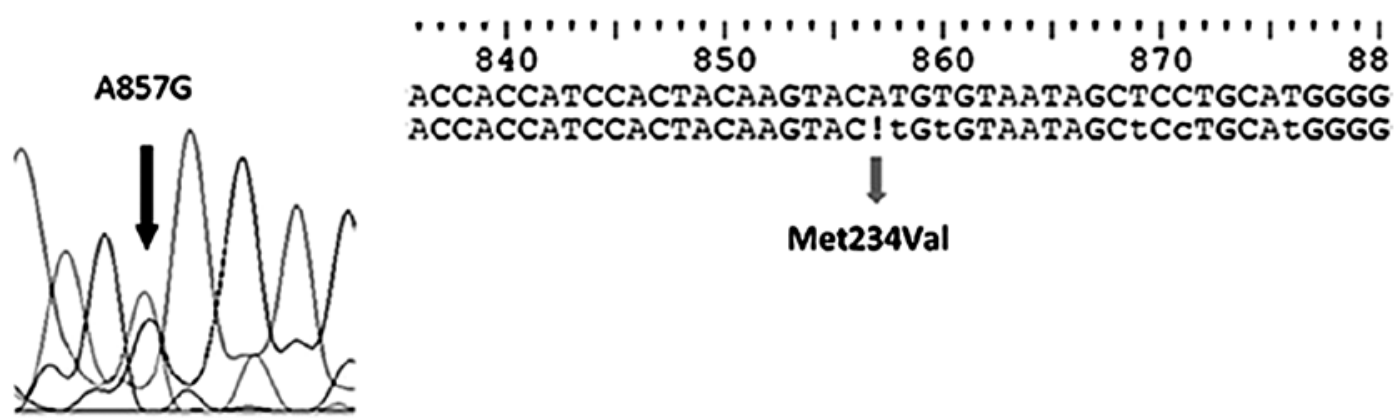

Fig. 1. Identified Trp53 mutations. (A) T854G (8-12-week-old control mouse), (B) G859A (7-month-old control mouse), (C) A929T (about 7-month-old PS/APP mice), (D) A857G (about 7-month-old PS/APP mice). 
However, analysis of $p 53, A \beta$ and $A \beta / A 4$ proteins' level were carried out in tree structures of the mice brain: GM, WM and C (Tables II and III, Fig. 2). PS/ APP mice showed tendency to a slightly lowered p53 level in GM and WM compared to controls of the same age and tendency to a greater increase in this protein level in these analyzed structures as compared to young controls (Table II). In PS/APP mice the increased level of $p 53$ protein was shown also in C as compared to controls (Table II).

All mice stained positive for the $A \beta / A 4$ protein precursor but only PS/APP mice were $A \beta$ positive (Fig. 2). In GM of PS/APP mice, a positive correlation between the levels of $p 53$ and $A \beta$ proteins (Spearman's test, $\left.R_{s}=+0.7000, p<0.05\right)$ was shown.

In GM of the 8-12-week-old control mouse with the Trp53 T854G mutation we found a lower level of p53 as compared to non-mutant mice of the same age (Table III, Fig. 2). On the other hand, in the older control mouse with the Trp53 G859A mutation, the p53 level in the GM was substantially elevated compared to respective non-mutant mice. The GM of PS/ APP mice with the Trp53 A929T and A857G mutations showed only moderate changes in p53 and $A \beta$ levels.

The study also revealed varying band staining intensities for the AB/A4 precursor. In all PS/APP and control mice there were triple bands, which were more intensive in GM and/or WM than in C (Fig. 2).

Due to the overwhelming sequence similarity between human and murine $\mathrm{p} 53$, especially within the DNA-binding core domain, we tried to estimate the potential influence of these four mutations on the protein activity with the use of the human IARC TP53 database that compiles TP53 variations identified in human populations and tumour samples $[31,45]$. Tyr233Asp, Met234lle and Met234Val generated possibly non-functional or partially functional

Table II. P53 protein levels in cerebral structures of PS/APP and control mice

\begin{tabular}{lccc}
\hline Cerebral structure & $\begin{array}{c}\text { Controls } \\
8-12 \text { week old }\end{array}$ & $\begin{array}{c}\text { Controls } \\
\text { about 7 month old }\end{array}$ & $\begin{array}{c}\text { PS/APP mice } \\
\text { about 7 month old }\end{array}$ \\
\hline Grey matter of the cortex (GM) & $27.4 \pm 11.2$ & $47.9 \pm 23.7$ & $44.5 \pm 15.7$ \\
\hline White matter (WM) & $29.6 \pm 6.6$ & $49.6 \pm 21.2$ & $44.3 \pm 15.8$ \\
\hline Cerebellum (C) & $32.5 \pm 5.8$ & $40.6 \pm 16.9$ & $45.2 \pm 10.7$
\end{tabular}

Results presented as the mean percentage area of immunoreactive bands \pm SD. Statistically insignificant differences in Kruskal-Wallis test ( $p>0.05)$. Spearman's test: Positive correlation found between $p 53$ levels in GM and WM in 7-month-old control mice $\left(R_{s}=+0.9762, p<0.001\right)$.

Positive correlation found in GM between $A \beta$ and $p 53$ proteins level in PS/APP mice $\left(R_{s}=+0.7000, p<0.05\right)$.

Table III. $\beta$-amyloid and p53 protein levels in cerebral structures of PS/APP and control mice

\begin{tabular}{|c|c|c|c|c|c|c|c|c|c|}
\hline & \multicolumn{9}{|c|}{ About 7 month old PS/APP mice } \\
\hline & \multicolumn{3}{|c|}{ Trp53 A929T (Ser258Cys) } & \multicolumn{3}{|c|}{ Trp53 A857G (Met234Val) } & \multicolumn{3}{|c|}{ No detected mutations in $\operatorname{Trp} 53$} \\
\hline & GM & WM & C & GM & WB & C & GM & WM & C \\
\hline$A \beta$ & {$[43.2-74.1]$} & {$[64.1-64.3]$} & {$[44.6-57.9]$} & {$[64.1-67.1]$} & {$[48.6-73.4]$} & {$[43.0-44.6]$} & {$[47.2-82.8]$} & {$[53.0-72.2]$} & {$[21.4-73.7]$} \\
\hline \multirow[t]{4}{*}{ p53 } & {$[32.7-43.8]$} & {$[24.1-59.0]$} & {$[45.8-46.1]$} & {$[35.0-45.9]$} & {$[27.9-41.7]$} & {$[36.0-45.4]$} & {$[25.0-65.1]$} & {$[26.3-67.7]$} & {$[27.8-68.0]$} \\
\hline & \multicolumn{9}{|c|}{ 8-12 week old control mice } \\
\hline & \multicolumn{4}{|c|}{ Trp53 T854G (Tyr233Asp) } & \multicolumn{5}{|c|}{ No detected mutations in $\operatorname{Trp} 53$} \\
\hline & GM & & WM & C & & GM & WM & & C \\
\hline \multirow[t]{4}{*}{ p53 } & {$[10.7]$} & & $26.5]$ & [38.9] & & $.3-40.5]$ & {$[19.1-38.2]$} & & $.6-36.0]$ \\
\hline & \multicolumn{9}{|c|}{ About 7 month old control mice } \\
\hline & \multicolumn{4}{|c|}{ Trp53 G859A (Met234lle) } & \multicolumn{5}{|c|}{ No detected mutations in $\operatorname{Trp} 53$} \\
\hline & GM & & WM & C & & GM & WM & & C \\
\hline p53 & {$[97.3]$} & & $66.7]$ & [34.6] & & $.9-60.5]$ & {$[21.5-83.4]$} & & 4.2-75.1] \\
\hline
\end{tabular}

Results presented as the mean percentage area of immunoreactive bands.

The range between minimum and maximum values or a single value is presented. 

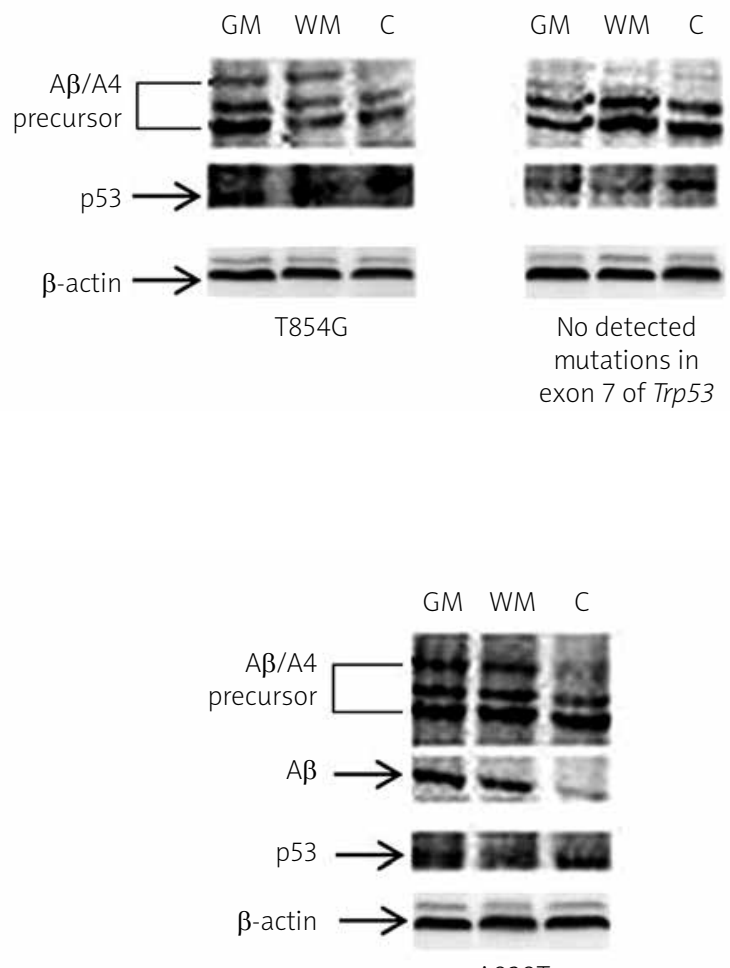

A929T

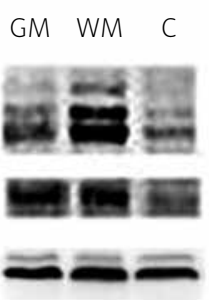

G859A
GM WM C

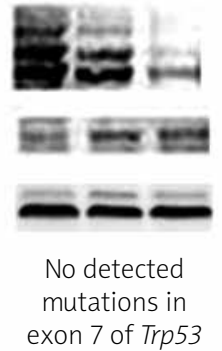

PS/APP mice

about 7-month-old

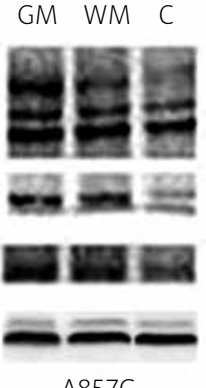

A857G

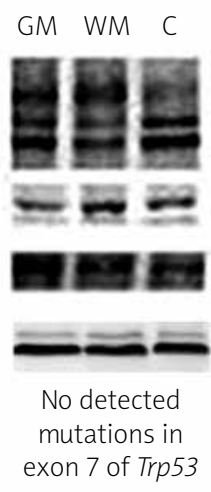

GM - grey matter of the cortex, WM - white matter, $C$-cerebellum, $A \beta$ - $\beta$-amyloid, $A \beta / A 4$-amyloid $A 4$ precursor

Fig. 2. Western blot analysis of $p 53, A \beta$ and $A \beta / A 4$ protein precursor in three cerebral structures of experimental mice.

proteins. Met234Val generated a possible new donor splice site, while Ser258Cys might abrogate the exon 7-8 splice site (Table IV, Figs. 3 and 4).

\section{Discussion}

Neuronal dysfunction in $A D$ is correlated with the deposition of fibrillar aggregates of $A \beta$ in brain parenchyma and blood vessel walls $[36,46]$. Double transgenic PS/APP mice show a rapid accumulation of both fibrillar and non-fibrillar (diffuse) forms of A $\beta$ from 12 weeks of age onwards [16,26]. In PS/APP mice, the number of fibrillar $A \beta$ deposits increases with age, whereas the changes are less marked in terms of the deposit numbers in the diffuse forms. It has been shown that in elderly mice, $A \beta$ is deposited in the cortex, hippocampus, thalamus and amygdala, but is additionally deposited in cerebellar cortex and
WM of AD patients $[16,25]$. Our study performed on PS/APP mice, along with the studies of Cummings et al. [13] in dogs and Feng et al. [17] in rats, demonstrates that $A \beta$ is deposited in the GM of the cortex but also the in $C$ and WM. Due to its deposition in the $C, A \beta$ may lead to learning and memory impairments [4]. The study in aged canines has shown that $A \beta$ deposition is strongly associated with deficits of discrimination, reversal and spatial learning [13]. Cummings et al. [13] suggest that $A \beta$ deposition may be a contributing factor to age-related cognitive dysfunction prior to the onset of NFTs formation.

The neurotoxic 42-43 amino acid long $A \beta$ peptide is a breakdown product of a much larger protein, the A $\beta / A 4$ protein precursor - APP [30]. It is known that the 4-4.5 $\mathrm{kDa} A \beta / A 4$ polypeptide is the major protein component of SPs [36]. The formation

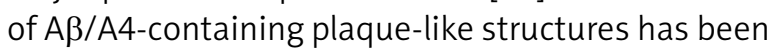


Table IV. Analysis of corresponding mutations in the human IARC TP53 database

\begin{tabular}{|c|c|c|c|c|}
\hline Murine mutation found & Trp53 Tyr233Asp & Trp53 Met234lle & Trp53 Met234Val & Trp53 Ser258Cys \\
\hline $\begin{array}{l}\text { Corresponding human } \\
\text { mutation }\end{array}$ & TP53 Tyr236Asp & TP53 Met237lle & TP53 Met237Val & TP53 Ser261Cys \\
\hline Mutation type & missense & $\begin{array}{c}\text { missense in } \\
\text { DNA-binding loops }\end{array}$ & $\begin{array}{c}\text { missense in } \\
\text { DNA-binding loops }\end{array}$ & missense \\
\hline $\begin{array}{l}\text { Assessment of transacti- } \\
\text { vation capacities in yeast } \\
\text { assays by Kato et al. [31] }\end{array}$ & non-functional & non-functional & partially functional & functional \\
\hline $\begin{array}{l}\text { Predicted effect on protein } \\
\text { function and structure }\end{array}$ & $\begin{array}{l}\text { deleterious, } \\
\text { non-functional }\end{array}$ & $\begin{array}{c}\text { deleterious, } \\
\text { non-functional }\end{array}$ & $\begin{array}{l}\text { deleterious, } \\
\text { non-functional }\end{array}$ & neutral, functional \\
\hline $\begin{array}{l}\text { Predicted effect on } \mathrm{p} 53 \\
\text { protein isoforms }\end{array}$ & all altered & all altered & all altered & all altered \\
\hline Dominant negative activity & yes & yes & NA & NA \\
\hline $\begin{array}{l}\text { Reported mutations } \\
\text { in human tumors }\end{array}$ & 9 & 185 & 12 & 1 \\
\hline Reported germline mutations & 0 & 1 & 0 & 0 \\
\hline Predicted effect on splicing & no significant change & no significant change & $\begin{array}{c}\text { acceptor: } \\
\text { no significant change } \\
\text { donor: new site }\end{array}$ & $\begin{array}{l}\text { sites broken or no } \\
\text { significant change }\end{array}$ \\
\hline
\end{tabular}

\section{$\begin{array}{rrr}176 & 179 \\ 1 & 190\end{array}$ \\ TP53 YKQSQHMTEVVRRCPHHERCSDSDGLAPPQHL IRVEGNLRVEYLDDRNTFRHSVV TrP53 YKKSQHMTEVVRRCPHHERCSDGDGLAPPQHL IRVEGNLYPEYLEDRQTFRHS VV $173176236237238 \quad 242 \quad 261$ \\ TP53 VPYEPPEVGSDCT T I HYNYMCNSSCMGGMNRRP I LT I I TLEDS SGNLLGRNSFEV TrP53 VPYEPPEAG SEYT T I HYKYMCN S SMGGMNRRP I LT I I T LEDS SGNLLGRDSFEV $233234235239 \quad 258$}

TP53 zinc-coordinating residues: Cys176, His179, Cys238, Cys242.

Trp53 zinc-coordinating residues: Cys173, His176, Cys235, Cys 239.

Trp53 identified mutated residues: Tyr233, Met234, Ser258.

Fig. 3. Human and murine p53 sequence alignment. Mutant and zinc-coordinating residues are shown.

found in GM and WM [5]. It has also been shown that $A \beta / A 4-$ related peptides may occur in both $A D$ and normal subjects, while their production is increased in familial AD, where the disease develops much earlier compared to sporadic $A D[12,36]$. It seems that pathological $A \beta / A 4$ with numerous extracellular $A \beta$ deposits, together with different levels of its precursor in GM and WM, may be included in the pathogenesis of $A D[20,30]$. Arendt et al. [5] have shown that $A \beta / A 4$ deposition is a result of a chronic disturbance of phosphorylation balance, which may lead to a reduction of both GM and WM in the AD brain. Moreover, it has been indicated that intraneuronal $A \beta$ may be a cause of mitochondrial [8], lysosomal [23,52] and synaptic [53] dysfunctions possibly leading to p53-dependent apoptosis [43] and reverse [18].

AD patients, p53-dependent apoptosis leads directly to neuronal loss through $A \beta 42$ binding and activation of the $\mathrm{p} 53$ promoter. The accumulation of both $A \beta 42$ and $p 53$ is manifested in some degenerating-shape neurons in both transgenic mice and AD. Our study demonstrated the presence of $A \beta$ in PS/ APP mice, along with a high p53 level compared to younger mice, which may indicate a possible induction of apoptosis. It has been shown that p53-dependent neuronal apoptosis may also result from a decreased activity of anti-apoptotic PS1 caused by $\mathrm{p} 53$ protein-protein interactions or by pro-apoptotic presenilin-2 (PS2), which down-regulates PS1 
expression [1,44]. It seems that the elevated p53 level influences the PS1-mediated abnormalities of intracellular calcium levels [14]. As a result, A $\beta, P S 1$, PS2 and p53 may all increase the risk of p53-dependent apoptosis in AD.

$\mathrm{P} 53$ is a key regulator of multiple cellular processes, and depending on the cell type it is activated by different stressors to induce apoptosis, autophagic cell death, but is also responsible for both, reversible and irreversible cell cycle arrest, or senescence [49]. The induction of cellular aging by elevated p53 levels in response to stress is designed to prevent proliferation of damaged cells.

Two main groups of signals change p53 activation. These include DNA damage and oncogenic stress as result from cancer and/or aging and may be an effect of p53 mutation [34]. Experimental PS/ APP mice have shown $44 \%$ of Trp53 gene mutations.

Loss of heterozygosity and TP53 mutations are commonly associated with a variety of tumours in humans and in experimental animals $[6,22,27]$. Mutations abrogating p53 function and allelic loss of its locus were among the first genetic lesions identified in glioblastoma multiforme [41]. TP53 mutations are also present in all grades of human astrocytoma [55] and in the murine model of astrocytoma [48].

A TP53 exon 7 missense mutation has been found in an adrenocortical carcinoma patient. Although the phenotype was not clinically distinct, authors suspect a hereditary background due to an early onset of the disease [56]. In this study we showed two missense mutations in PS/APP mice: A929T (Ser258Cys) and A857G (Met234Val), possibly altering $p 53$ function as both are located within the central DNA-binding core domain (DBD). The DBD is responsible for binding LIM domain only protein 3 (LMO3), which is a confirmed human neuroblastoma oncogene [35]. Reverse $\mathrm{Val} \rightarrow$ Met substitutions at codons 216 and 272 have also been demonstrated in brain carcinoma, and this mutation is particularly important in mediating the normal function of p53 [41]. Mineta et al. [38] have demonstrated a TP53 exon 7 Ser241Cys substitution in head and neck tumours. Moreover, patients with p53 missense or nonsense mutations survived an average of only 12.5 months after diagnosis, while non-mutated subjects survived more than 160 months after diagnosis, and $43 \%$ of these examined tumours presented a low p53 level and 32\% had increased p53 levels. It seems that also mutant Trp53 tends to impact the

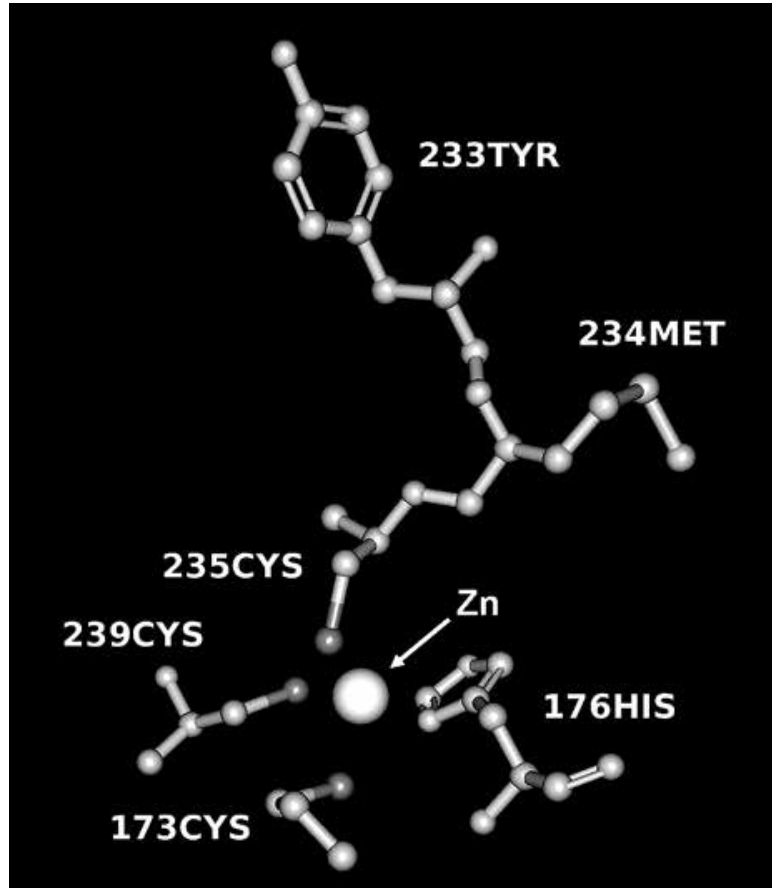

Zinc-coordination: Cys173, His176, Cys235, Cys239. Identified mutated residues: Tyr233, Met234. Zinc (Zn) atom is indicated by an arrow. Not all atoms are shown for clarity of image.

Fig. 4. Coordination of zinc in p53. Based on 1HU8 crystal structure by Zhao et al. [58].

p53 expression level in all analyzed structures of experimental PS/APP mice.

Our study also demonstrated a missense mutation (T854G) in a young control mouse, resulting in a Tyr233Asp substitution, along with a tendency to a low p53 expression in the GM. Reilly et al. [48] have shown that the TP53 gene is often mutated in a subset of astrocytomas that develop at a young age and progress slowly to glioblastoma [55]. Nonetheless, one of our 7-month-old control mice showed a G859A (Met244lle) missense mutation, which seems to be related with an increased p53 level in GM. Overexpression of p53 in the process of aging has been shown by Tyner et al. [54], Garcia-Cao et al. [21] and Mendrysa et al. [37], and is accompanied by decreased longevity, osteoporosis, generalized organ atrophy, and diminished stress tolerance.

All of the aforementioned mutations, apart from the Tyr233Asp substitution, involve either removal or introduction of sulphur atoms into p53. Three of our mutations (Tyr233Asp, Met234lle, Met234Val), along with the mutation found by Mineta et al. [55] (Ser241Cys in TP53, corresponding to Ser238Cys in Trp53), are located in or neighbour loop 3 - a region rich in 
methionine and cysteine residues. It has been found that two of these residues, i.e. Cys235 and Cys239, along with Cys173 and His176, coordinate a zinc atom forming a structure crucial for DNA binding $[11,47]$. The Ser238Cys substitution [55] is therefore located one residue upstream of a zinc-coordinating cysteine. The identified Met234lle and Met234Val substitutions are also located one residue upstream of such a cysteine, while the Tyr233Asp is just two residues upstream [58]. Although the Ser258Cys substitution is located downstream of the zinccoordinating domain, not only does it disturb a double serine motif, but more importantly it spans across the exon 7-8 junction. The corresponding A929T substitution decreases the mathematical score of the 5' splice site, but its impact on the site stability remains undetermined. Although both mutations found in PS/APP mice could possibly inactivate p53, their effect on p53 and A $\beta$ levels is not so apparent, most likely due to heterozygosity and the fact that a faulty p53 could still bind its antibody. Similarly, the reason that the Met234lle and Tyr233Asp substitutions would impact p53 levels in the GM of control mice remains unsolved.

In conclusion, the transgenic PS/APP mice, which simulate AD, carry a missense Trp53 exon 7 mutations about four times more frequently than controls. In PS/APP mice, the A929T (Ser258Cys) and A857G (Met234Val) mutations may alter p53 expression in a similar manner. However, in the GM of the control younger mouse, the Trp53 T854G (Tyr233Asp) mutation may be connected with a decreased level of p53, while in the same structure of the brain of the control 7-month-old mouse, the Trp53 G859A (Met234lle) mutation may be associated with increased the p53 level as compared to non-mutated mice of the same age. Moreover, the GM of PS/APP mice has shown a positive correlation between levels of $p 53$ and A $\beta$. Trp53 mutations found in this study may impact the murine p53 function as shown by the in silico analysis and possibly also be associated with the degenerative process.

\section{References}

1. Alves da Costa C, Paitel E, Mattson MP, Amson R, Telerman A, Ancolio K, Checler F. Wild-type and mutated presenilins 2 trigger p53-dependent apoptosis and down-regulate presenilin 1 expression in HEK293 human cells and in murine neurons. Proc Natl Acad Sci U S A 2002; 99: 4043-4048.

2. Armstrong RA. On the 'classification' of neurodegenerative disorders: discrete entities, overlap or continuum? Folia Neuropathol 2012; 50: 201-218
3. Armstrong RA. What causes Alzheimer's disease? Folia Neuropathol 2013; 51: 169-188.

4. Atkins ER, Panegyres PK. The clinical utility of gene testing for Alzheimer's disease. Neurol Int 2011; 3: e1.

5. Arendt T, Holzer M, Fruth R, Brückner MK, Gärtner U. Paired helical filament-like phosphorylation of tau, deposition of beta/ A4-amyloid and memory impairment in rat induced by chronic inhibition of phosphatase 1 and 2A. Neuroscience 1995; 69: 691-698.

6. Bougeard G, Brugieres L, Chompret A, Gesta P, Charbonnier F, Valent A, Martin C, Raux G, Feunteun J, Bressac-de Paillerets B, Frébourg T. Screening for TP53 rearrangements in families with the Li-Fraumeni syndrome reveals a complete deletion of the TP53 gene. Oncogene 2003; 22: 840-846.

7. Boyd JA, Barrett JC. Tumor suppressor genes: possible functions in the negative regulation of cell proliferation. Mol Carcinog 1990; 3: 325-329.

8. Busciglio J, Pelsman A, Wong C, Pigino G, Yuan M, Mori H, Yankner BA. Altered metabolism of the amyloid beta precursor protein is associated with mitochondrial dysfunction in Down's syndrome. Neuron 2002; 33: 677-688.

9. Chen Z, An S, Xie Z, Yan H, Chen J, Su J, Zhang X, Niu F, Guo W, Wu Y. High resolution melting analysis for detecting p53 gene mutations in patients with non-small cell lung cancer. Zhongguo Fei Ai Za Zhi 2011; 14: 767-773.

10. Chiaretti S, Tavolaro S, Marinelli M, Messina M, Del Giudice I, Mauro FR, Santangelo S, Piciocchi A, Peragine N, Truong S, Patten N, Ghia EM, Torrente I, De Propris MS, Nanni M, Lawrence J, Guarini A, Foà R. Evaluation of TP53 mutations with the AmpliChip p53 research test in chronic lymphocytic leukemia: correlation with clinical outcome and gene expression profiling. Genes Chromosomes Cancer 2011; 50: 263-274.

11. Cho Y, Gorina S, Jeffrey PD, Pavletich NP. Crystal structure of a p53 tumor suppressor-DNA complex: understanding tumorigenic mutations. Science 1994; 265: 346-355.

12. Citron M, Oltersdorf T, Haass C, McConlogue L, Hung AY, Seubert P, Vigo-Pelfrey C, Lieberburg I, Selkoe DJ. Mutation of the beta-amyloid precursor protein in familial Alzheimer's disease increases beta-protein production. Nature 1992; 360: 672-674.

13. Cummings BJ, Head E, Afagh AJ, Milgram NW, Cotman CW. Beta-amyloid accumulation correlates with cognitive dysfunction in the aged canine. Neurobiol Learn Mem 1996; 66: 11-23.

14. Das HK, Tchedre K, Mueller B. Repression of transcription of presenilin-1 inhibits $\gamma$-secretase independent ER $\mathrm{Ca}(2+)$ leak that is impaired by FAD mutations. J Neurochem 2012; 122: 487 500.

15. Dorszewska J. Cell biology of normal brain aging: synaptic plasticity - cell death. Aging Clin Exp Res 2013; 25: 25-34.

16. Dyrks T, Dyrks E, Monning U, Urmoneit B, Turner J, Beyreuther K. Generation of beta A4 from the amyloid protein precursor and fragments thereof. FEBS Lett 1993; 335: 89-93.

17. Feng C, Zhang C, Shao X, Liu Q, Qian Y, Feng L, Chen J, Zha Y, Zhang $Q$, Jiang $X$. Enhancement of nose-to-brain delivery of basic fibroblast growth factor for improving rat memory impairments induced by co-injection of $\beta$-amyloid and ibotenic acid into the bilateral hippocampus. Int J Pharm 2012; 423 : 226-234. 
18. Fiorini A, Sultana R, Barone E, Cenini G, Perluigi M, Mancuso C, Cai J, Klein JB, St Clair D, Butterfield DA. Lack of p53 affects the expression of several brain mitochondrial proteins: insights from proteomics into important pathways regulated by $\mathrm{p} 53$. PLoS One 2012; 7: e49846.

19. Frain L, Driver J, Gaziano JM, Lu KP, Kowall N, Gagnon D, Cho K, Betensky R, Swanson D. A reduced risk of Alzheimer Disease is associated with the majority of cancers in a National cohort of Veterans. Alzheimer's Association International Conference, Boston 2013; P3-175.

20. Games D, Adams D, Alessandrini R, Barbour R, Berthelette P, Blackwell C, Carr T, Clemens J, Donaldson T, Gillespie F. Alzheimer-type neuropathology in transgenic mice overexpressing V717F beta-amyloid precursor protein. Nature 1995; 373: 523-527.

21. Garcia-Cao I, Garcia-Cao M, Martin-Caballero J, Criado LM, Klatt P, Flores JM, Weill JC, Blasco MA, Serrano M. "Super p53" mice exhibit enhanced DNA damage response, are tumor resistant and age normally. EMBO J 2002; 21: 6225-6235.

22. Gavino C, Richard S. Loss of p53 in quaking viable mice leads to Purkinje cell defects and reduced survival. Sci Rep 2011; 1: 84.

23. Glabe C. Intracellular mechanisms of amyloid accumulation and pathogenesis in Alzheimer's disease. J Mol Neurosci 2001; 17: $137-145$

24. Harano H, Wang C, Gao J, Uchida T. p53 tumor suppressor gene mutation and prognosis in 105 cases of bladder cancer-the relationship between mutation of the p53 gene with clinicopathological features and smoking. Nihon Hinyokika Gakkai Zassh 1999; 90: 487-495.

25. Hirai S, Okamoto K. Amyloid beta/A4 peptide associated with Alzheimer's disease and cerebral amyloid angiopathy. Intern Med 1993; 32: 923-925.

26. Holcomb L, Gordon MN, McGowan E, Yu X, Benkovic S, Jantzen P, Wright K, Saad I, Mueller R, Morgan D, Sanders S, Zehr C, O'Campo K, Hardy J, Prada CM, Eckman C, Younkin S, Hsiao K, Duff K. Accelerated Alzheimer-type phenotype in transgenic mice carrying both mutant amyloid precursor protein and presenilin 1 transgenes. Nat Med 1998; 4: 97-100.

27. Hollstein M, Sidransky D, Vogelstein B, Harris CC. p53 mutations in human cancers. Science 1991; 253: 49-53.

28. Hope J, Kirby L. Amyloid and prions: some biochemical investigations of cerebral amyloidosis in mice. Folia Neuropatho 2012; 50: 13-19.

29. Jacks T, Remington L, Williams BO, Schmitt EM, Halachmi S, Bronson RT, Weinberg RA. Tumor spectrum analysis in p53-mutant mice. Curr Biol 1994; 4: 1-7.

30. Kang J, Lemaire HG, Unterbeck A, Salbaum JM, Masters CL, Grzeschik KH, Multhaup G, Beyreuther K, Müller-Hill B. The pre cursor of Alzheimer's disease amyloid A4 protein resembles a cell-surface receptor. Nature 1987; 325: 733-736.

31. Kato S, Han SY, Liu W, Otsuka K, Shibata H, Kanamaru R, Ishioka C. Understanding the function-structure and function-mutation relationships of p53 tumor suppressor protein by high-resolution missense mutation analysis. Proc Natl Acad Sci U S A 2003; 100: 8424-8429.

32. LaFerla FM, Hall CK, Ngo L, Jay G. Extracellular deposition of beta-amyloid upon p53-dependent neuronal cell death in transgenic mice. J Clin Invest 1996; 98: 1626-1632.
33. Lanni C, Racchi M, Uberti D, Mazzini G, Stanga S, Sinforiani E, Memo M, Govoni S. Pharmacogenetics and pharmagenomics, trends in normal and pathological aging studies: focus on p53. Curr Pharm Des 2008; 14: 2665-2671.

34. Lanni C, Racchi M, Memo M, Govoni S, Uberti D. p53 at the crossroads between cancer and neurodegeneration. Free Radic Biol Med 2012; 52: 1727-1733.

35. Larsen S, Yokochi T, Isogai E, Nakamura Y, Ozaki T, Nakagawara A. LMO3 interacts with $\mathrm{p} 53$ and inhibits its transcriptional activity. Biochem Biophys Res Commun 2010; 392: 252257.

36. Matsuoka Y, Picciano M, Malester B, LaFrancois J, Zehr C, Daeschner JM, Olschowka JA, Fonseca MI, O’Banion MK, Tenner AJ, Lemere CA, Duff K. Inflammatory responses to amyloidosis in a transgenic mouse model of Alzheimer's disease. Am J Pathol 2001; 158: 1345-1354.

37. Mendrysa SM, O'Leary KA, McElwee MK, Michalowski J, Eisenman RN, Powell DA, Perry ME. Tumor suppression and normal aging in mice with constitutively high p53 activity. Genes Dev 2006; 20: 16-21.

38. Mineta H, Borg A, Dictor M, Wahlberg P, Akervall J, Wennerberg J. p53 mutation, but not p53 overexpression, correlates with survival in head and neck squamous cell carcinoma. $\mathrm{Br}$ J Cancer 1998; 78: 1084-1090.

39. Moreland JL, Gramada A, Buzko OV, Zhang Q, Bourne PE. The Molecular Biology Toolkit (MBT): a modular platform for developing molecular visualization applications. BMC Bioinformatics 2005; 6: 21.

40. Neve RL, Robakis NK. Alzheimer's disease: a re-examination of the amyloid hypothesis. Trends Neurosci 1998; 21: 15-19.

41. Nigro JM, Baker SJ, Preisinger AC, Jessup JM, Hostetter R, Cleary K, Bigner SH, Davidson N, Baylin S, Devilee P. Mutations in the p53 gene occur in diverse human tumour types. Nature 1989; 342: 705-708.

42. Ohnishi T, Inoue N, Matsumoto H, Omatsu T, Ohira Y, Nagao$\mathrm{ka}$ S. Cellular content of p53 protein in rat skin after exposure to the space environment. J Appl Physiol 1996; 81: 183-185.

43. Ohyagi Y, Asahara H, Chui DH, Tsuruta Y, Sakae N, Miyoshi K, Yamada T, Kikuchi H, Taniwaki T, Murai H, Ikezoe K, Furuya H, Kawarabayashi T, Shoji M, Checler F, Iwaki T, Makifuchi TT, Takeda K, Kira J, Tabira T. Intracellular Abeta42 activates p53 promoter: a pathway to neurodegeneration in Alzheimer's disease. FASEB J 2005; 19: 255-257.

44. Pastorcic M, Das HK. Regulation of transcription of the human presenilin-1 gene by ets transcription factors and the p53 protooncogene. J Biol Chem 2000; 275: 34938-34945.

45. Petitjean A, Mathe E, Kato S, Ishioka C, Tavtigian SV, Hainaut P, Olivier M. Impact of mutant p53 functional properties on TP53 mutation patterns and tumor phenotype: lessons from recent developments in the IARC TP53 database. Hum Mutat 2007; 28: 622-629.

46. Pluta R, Kocki J, Maciejewski R, Ułamek-Kozioł M, Jabłoński M, Bogucka-Kocka A, Czuczwar SJ. Ischemia signalling to Alzheimer-related genes. Folia Neuropathol 2012; 50: 322-329.

47. Rainwater R, Parks D, Anderson ME, Tegtmeyer P, Mann K. Role of cysteine residues in regulation of p53 function. Mol Cell Biol 1995; 15: 3892-3903. 
48. Reilly KM, Loisel DA, Bronson RT, McLaughlin ME, Jacks T. Nf1;Trp53 mutant mice develop glioblastoma with evidence of strain-specific effects. Nat Genet 2000; 26: 109-113.

49. Sakamoto Y, Kato S, Takahashi M, Okada Y, Yasuda K, Watanabe G, Imai H, Sato A, Ishioka C. Contribution of autophagic cell death to p53-dependent cell death in human glioblastoma cell line SF126. Cancer Sci 2011; 102: 799-807.

50. Serrano J, Fernández AP, Martínez-Murillo R, Martínez A. High sensitivity to carcinogens in the brain of a mouse model of Alz heimer's disease. Oncogene 2010; 29: 2165-2171.

51. Šerý O, Povová J, Míšek I, Pešák L, Janout V. Molecular mechanisms of neuropathological changes in Alzheimer's disease: a review. Folia Neuropathol 2013; 51: 1-9.

52. Shie FS, LeBoeuf RC, Jin LW. Early intraneuronal Abeta deposition in the hippocampus of APP transgenic mice. Neuroreport 2003; 14: 123-129.

53. Takahashi RH, Milner TA, Li F, Nam EE, Edgar MA, Yamaguchi H, Beal MF, Xu H, Greengard P, Gouras GK. Intraneuronal Alzheimer abeta42 accumulates in multivesicular bodies and is associated with synaptic pathology. Am J Pathol 2002; 161: 1869-1879.

54. Tyner SD, Venkatachalam S, Choi J, Jones S, Ghebranious N, Igelmann H, Lu X, Soron G, Cooper B, Brayton C, Park SH, Thompson T, Karsenty G, Bradley A, Donehower LA. p53 mutant mice that display early ageing-associated phenotypes. Nature 2002; 415: 45-53.

55. Watanabe K, Sato K, Biernat W, Tachibana O, von Ammon K, Ogata N, Yonekawa Y, Kleihues P, Ohgaki H. Incidence and timing of p53 mutations during astrocytoma progression in patients with multiple biopsies. Clin Cancer Res 1997; 3: 523-530.

56. Waldmann J, Patsalis N, Fendrich V, Langer P, Saeger W, Chaloupka B, Ramaswamy A, Fassnacht M, Bartsch DK, Slater EP. Clinical impact of TP53 alterations in adrenocortical carcinomas. Langenbecks Arch Surg 2012; 397: 209-216.

57. Xu XM, Qian JC, Cai Z, Tang T, Wang P, Zhang KH, Deng ZL, Cai JP. DNA alterations of microsatellite DNA, p53, APC and K-ras in Chinese colorectal cancer patients. Eur J Clin Invest 2012; 42: 751-759.

58. Zhao K, Chai X, Johnston K, Clements A, Marmorstein R. Crystal structure of the mouse p53 core DNA-binding domain at 2.7 A resolution. J Biol Chem 2001; 276: 12120-12127. 